\title{
16 Archives for truth and justice in Argentina
}

\author{
The search for the missing \\ persons
}

Mariana Nazar

\section{Introduction}

On 24 March 1976, in the context of a growing wave of repression, a civilmilitary dictatorship took power through a coup d'état in Argentina.

From that point on, the provincial governors were dismissed; the National Congress and the provincial legislatures were dissolved; the members of the Supreme Court of Justice were ousted; and trade unions and political parties were outlawed. Although disruptions of the democratic order, repression of conflicts between different social sectors; and appeals to violence had all been frequent throughout the 20th century, the dictatorship that commenced in 1976 was characterised by a degree of violence unheard of up till then, in particular, due to the introduction of state terrorism and the systematic application of a particular type of political crime: the forced disappearance of persons.

This form of illegal and systematic extermination was aimed at social and political militants who had been characterised as subversive elements. As Crenzel (2015) points out, the disappearances combined public and clandestine phases, because the detentions were usually carried out by members of the armed forces or security forces, either in uniform or civilian clothes, on public thoroughfares, or in private houses, and in the presence of witnesses. Detainees were then taken to clandestine detention centres, where they were tortured and, in the vast majority of cases, murdered and their bodies done away with secretly. From the investigations carried out so far, it is known that their bodies were either buried in anonymous graves, cremated or thrown into the sea.

Faced with these facts, a section of society denounced this, demanding to be told where the missing persons were and insisting that they reappear alive. During this period, already existing human rights organizations, such as the Argentine League for Human Rights (Liga Argentina por los Derechos del Hombre), created in the 1930s, were joined by others set up to denounce and resist the extreme political violence exercised by the State, with the aim of seeking the whereabouts of the missing persons, and taking legal action on the disappearances, such as the Peace and Justice Service 
Foundation (SERPAJ: Fundación Servicio Paz y Justicia, 1974); the Permanent Assembly for Human Rights (APDH: Asamblea Permanente por los Derechos Humanos, 1975); the Ecumenical Movement for Human Rights (MEDH: Movimiento Ecuménico por los Derechos Humanos, 1976); Relatives of the Missing Persons and Political Detainees (Familiares de Desaparecidos y Detenidos por Razones Politicas, 1976); Mothers of the Plaza de Mayo (Madres de la Plaza de Mayo, 1977); or the Centre for Legal and Social Studies (CELS: Centro de Estudios Legales y Sociales, 1979), among others.

These actions in favour of the national memory, truth and justice have been linked from the outset to legal claims concerning the existence of, and access to, documents that provide an account of the State's terrorist actions, insofar as these documents could serve as evidence to ascertain the fate of those who disappeared and establish liability, as well as being possible sources of the country's history and its memory. Just as the government denied and, at the same time, oversaw the existence of enforced disappearances, the perpetrators continued to deny the existence of documents that accounted for these processes.

The documents, as the basis for the actions of institutions - and in the absence of any official archival policies that would ensure transferrals and access - remained in the hands of these same forces. The possibility of any knowledge of, and access to, these was therefore subject to the public policies exercised by these same institutions.

For this reason, in this chapter, we shall present the responses which have been provided by the State, since the return to democracy in 1983, to the demand for access to documentation on the forced disappearance of persons, specifically presenting those provided during the Kirchner period (successive Kirchner governments, 2003-2015), because these demonstrated a firm will to devise reparations policies.

\section{The documents on the missing persons}

As stated earlier, from before the end of the dictatorship, relatives, survivors, organizations and individuals committed to political militancy, or the defence of human rights, have demanded access to the documentation produced during the dictatorship, which would provide an account of the repressive action taken by the State.

The Armed Forces and Security Forces have stated, historically, that all documentation from the period of the repression has been destroyed, referring to legislation passed during the last days of the Dictatorship (e.g. Decree 2726/83), which ordered the deregistering of all records on detention of arrested persons available to the National Executive, in an attempt to "pacify the country". In addition, a radio message was broadcast from the Commander-in-Chief of the Army, dated 23 November 1983, ordering the destruction of documentation related to what was termed "the fight against 
subversion". Nevertheless, some sporadic findings highlighted that it was necessary to continue the searches, as well as reconfiguring their format.

As one of the demands of society was to open up the archives, it became necessary to rethink which types of archives; in which records traces of the actions of state terrorism could be found; and how to establish crossreferences between them to supplement information.

Within the State, documents have been produced which refer to clandestine activities; some as a register of illegal activities and others as a means of bureaucratic back-up for the organization of these clandestine actions.

When members of the security forces declare that the documents were destroyed once their action had concluded, ${ }^{1}$ we understand that they are referring to the documents most closely linked to the illegal activities. For this reason, the conservation of some documents that provide an account of this action, in a direct way, was due to an act of conscious resistance, of intentional concealment, or the discovery of parts of documents during the actual trials.

A paradigmatic case of resistance is that of the photographs that Víctor Basterra, a detained activist who disappeared in the clandestine centre operating in the Navy's School of Mechanics (ESMA: Escuela de Mecánica de la Armada), managed to secretly remove. ${ }^{2}$ Another might be, because their origin is unknown, the intelligence documents containing statements taken at ESMA, published in 2009, under the name of the ESMA Documents, published by de la Campana (Documentos de la ESMA por Editorial de la Campana). But there were also cases of intentional concealment or use as an exchange pledge, such as the summary papers on the operations of the Army's 601st Battalion, provided by Orestes Estanislao Vaello, a former member of Army Intelligence, who gave testimony as a repentant witness before the National Commission for the Disappearance of Persons (CONADEP: Comisión Nacional por la Desaparición de Personas (File No. $3,675)$.

As pointed out in a CELS report:

Information disseminated by marginal publications and websites, nostalgic about state terrorism, to disqualify former militants in the $70 \mathrm{~s}$ (with data obtained in torture sessions and therefore from sources impossible to cite), added to the progressive reappearance of former repressors in government offices, bent on exchanging information for impunity, and the receipt at federal courts of official reports prepared during the dictatorship, all demonstrate that documentation which is, a priori, inaccessible to civil servants and magistrates, in fact circulates freely among the repressors and apologists of the dictatorship.

(Varsky et al., 2008, p. 62)

Some stray documents have also been found during court proceedings ${ }^{3}$ which, in some cases, have been circulated in journalistic investigations; ${ }^{4}$ or during projects to identify police documentation, as in the case of the 
horrifying logbook or bitácora which was kept by the repressor, Agustín Feced, in the Information Service of the Santa Fe Police, and which was found among the documentation of the Buenos Aires Police Intelligence HQ.

For this reason, a few years ago the strategy adopted was to investigate the documentation on the activities that had already been regulated by the State, in order to sustain this action. This is a complex task, insofar as it requires the coordination of various different institutions and organizations involved, to do this efficiently. It also requires a change of perspective in the search, because concepts, such as the archives of the dictatorship (implying a chronological cut-off point); the archives of the repression, which focus on the institutions which acted in this repression; or archives on human rights, focusing on the social organizations which acted through resistance, prove in the end to be inefficient.

This repressive action has left its mark not only on institutions with directly repressive functions, but also on other state institutions, and even on those of a society that was committed (by action, omission or opposition) to this.

\section{Public policies in response to the demand for a memory, truth and justice and archive documents}

Over the course of these almost 40 years, the appearance of archival documents has been closely linked to the political decisions and possibilities of each government.

When the last military dictatorship ended, and only five days after taking his seat in the democratic government, President Raúl Alfonsín decreed the prosecution of the Military Juntas and created the CONADEP. This body was to investigate human rights violations during the period of state terrorism and investigate the fate of those who had disappeared.

The final report of the investigation submitted in 1984 reported the existence of thousands of missing persons from 380 clandestine detention centres, and maintained that these events were the result of a systematic plan perpetrated by the government (which made this a key element in the trial of the military Juntas, ${ }^{5}$ held in 1985). This was published in book form under the name Nunca Más (Never Again) and the section referring to the problems of access to documentation states that "it has been possible to determine that there was a significant accumulation of documentation which has been destroyed, or which is kept hidden by the perpetrators of the repressive action". (CONADEP, 1997, p. 274).

After mentioning that the repressive operation mounted, due to its size and scope, must have required the use of supporting documentation, and that there is knowledge of orders for its destruction, as well as, presumably, concealment under the protection of military secrecy, it was concluded:

In fact, by destroying or concealing the documentation, the burden of proof has been reversed for the acts of the utmost gravity, committed during the de facto government, transferring over to this Commission, 
to the Judiciary and to the public in general, the difficult task of reconstructing events, with the scarce documentation available. However, on the basis of the statements obtained from those who were released, relatives of missing persons, members of the security forces and the few documents found, it has been possible to ascertain the essence of the illegal repressive action that was carried out.

(CONADEP, 1997, p. 275)

At the end of its work, CONADEP had produced an archive which, among other things, gathered together the largest number of reports and information on the disappearance of persons to date, totalling 8,960 cases. As Emilio Crenzel points out:

[A] significant number of them, 5580, were handed over to the Commission by Argentina's Permanent Assembly for Human Rights [APDH in its Spanish acronym], which had amassed them during the dictatorship and handed them over to the IACHR [Inter-American Commission on Human Rights] in 1979.

(Crenzel, 2015, p. 160)

In this way, the testimony of the survivors became the basic input for tracing the events that some intended to erase. ${ }^{6}$

In 1986, before the end of this presidential term, the court cases were blocked by the enactment of the Full Stop Law (Ley de Punto Final) and, in 1987, the Law of Due Obedience (Ley de Obediencia Debida).

In the following government, under Carlos Menem (1989-1999), along with the reintroduction of the neoliberal model, the work of the justice system was totally paralysed and a presidential decree pardoned the members of the military juntas who had been condemned, along with a number of high-ranking military officers who were still on trial. On the other hand, economic reparations measures were laid down for the victims of human rights violations committed between 1974 and 1983.

The year 2003 saw the start of the Kirchner governments when Néstor Kirchner took office as President of Argentina, with the Kirchners remaining in office until December 2015. One of the aspects that identified these governments was a new impulse - now maintained over time - in favour of reparatory public policies on state-led terrorism.

These policies were related to creating the necessary conditions for the punishment of the crimes, state recognition of the crimes, the search for truth, publicising what had occurred and economic reparation for the victims. This process of reparation had a very high social impact, insofar as it came hand in hand with policies for satisfaction, as regards the measures of both recognition and apology, and the policies on the country's memory. ${ }^{7}$ Likewise, new reparations laws ${ }^{8}$ were passed, and in the sphere of justice, measures began to make progress in the determination of criminal 
liability, generating the political and cultural conditions necessary to obtain new criminal trials. In 2003, the Due Obedience and Full Stop laws were repealed, and in 2005 the Supreme Court declared them unconstitutional. These exceptional advances made it imperative to locate documentation.

In relation to memory policies, this was a process linked to a general phenomenon, known as the explosion of the memory: a time marked by the proliferation of memorials, museums, commemorations and various cultural events to remember the past. In this direction, we are particularly interested in presenting the role of archives within these policies. Because these policies were focused centrally on memory and reparations, it was considered that the problem of archive documents would be resolved during the exercise of this policy. This perspective had, as its key landmark, the creation of the Archives of the Memory which, in some cases, did nothing more than directly attack precisely what they wanted to preserve.

\section{Among archives of the memory, research teams and general archives}

During 2003-2015, the documentation identified as being linked to human rights violations served various purposes.

In the first place, we should highlight that one of the first institutional moves to assess documents as sources of memory was produced by civil society, with the inauguration of the Open Memory (2000: Memoria Abierta) as an alliance of human rights organizations aimed at bolstering the memory of human rights violations, the resistance and the struggle for truth and justice.

At government level, specific institutions, the so-called Archives of the Memory (Archivos de la Memoria), were created. These were set up with a view to formulating policies oriented more towards a national memory, rather than preserving archives, and included functions that ranged from gathering, systematising and preserving documents from a particular period to contributing to prevention, investigation and prosecution of cases of human rights violations, promoting studies and research, setting up information networks, recovering property from clandestine centres, undertaking tasks of dissemination and education and even holding exhibitions or displays, courses, conferences, monuments, etc.

Somehow, in these institutions, the role of the archive was not defined as such, and a large proportion of archives created in Argentina do not hold any original documents, or even copies of them.

The first government-led memorial centre and archive created in Argentina was the Buenos Aires Provincial Memory Committee (CPM: Comisión Provincial por la Memoria) in the year 2000. Subsequently, and at national level, the National Memory Archive was set up in 2003. Today, with the exception of the provinces of Catamarca and Entre Ríos, each province has a Memory Centre which should fulfil the functions of an archive. In 
addition, there are Provincial Memory Committees in Córdoba, Santa Fe, La Pampa, Chaco, Mendoza, Misiones and Río Negro; Memory Archives in Salta, Chubut and La Rioja; Municipal Memory Archives in Corrientes; a Memory Space in the city of Buenos Aires and Formosa; a Memory Library in Jujuy; and there are currently plans to create a Memory Archive or museum in Neuquén.

Additionally, after the reopening of the trials for crimes against humanity, and in order to be able to provide supporting documentation, specific areas began to be set up for the collection of documentation that could be provided as evidence.

The first one was in the Ministry of Defence (to which the three Armed Forces report: Army, Navy and Air Force), within the Directorate of Human Rights and under International Humanitarian Law (2006), where an investigation team began operating in 2009, followed later, in 2011, by the Archive Modernisation Programme.

In 2011, the Special Group for Documentary Surveillance was created within the Human Rights Office in the Ministry of Security (to which the security forces report: Federal Police, National Gendarmerie and Prefecture). Also, in that year the Human Rights Office was set up in the National Securities Commission and the Commission for the Recovery of the Historical Memory was set up within the Ministry of Foreign Affairs. In 2014, a Human Rights sub-directorate was set up in Argentina's Central Bank.

Furthermore, we should also point out that the General Archive of the Nation, the General Archive of the Province of Santa Fe and the Historical Archive of the Province of Buenos Aires also received transferrals of document fonds on the violation and/or defence of human rights.

Each of these areas or institutions has designed the archives in a particular way, thus deciding on the processing of and purpose served by the documents. ${ }^{9}$ In this regard, we will briefly look at the cases which we consider have best weathered these tensions and overcome these difficulties, succeeding in reversing any possible manipulation of their document fonds. ${ }^{10}$

The first case to be mentioned is that of the Buenos Aires Provincial Memory Committee (CPM in its Spanish acronym). This was created in 2000 to preserve the documentation of the Police Intelligence Headquarters for the Province of Buenos Aires (DIPPBA) and make it publicly accessible. One of the first tasks it undertook was to digitise all the documentation, totalling 336 metres in length (predominant basic dates 1957-1998), after which, in 2003 , it was possible to open it up to the public for consultation, however only through reference library staff who made keyword searches using OCR (optical character recognition).

At that time, it was thought that digitization and OCR were the most efficient form of search, and that the mediating the investigations through the CPM staff - who ran the search and delivered copies of the documentation with the names crossed out - was the best way to preserve the sensitive data on those under investigation. As time went by, and the limitations of 
keyword searches became clear, there was also a need to understand the contexts in which documents had been produced, to make sense of the literal information they contained, as well as considering the deeply subjective significance of mediation in the research process. Thus, new lines of development were adopted, introducing archiving, as a discipline, into document processing.

The result was an intensive process to identify, classify and describe the fonds, its sections and series, published in 2010, ${ }^{11}$ with other methods of consultation becoming available in 2013 (Lanteri and Nazar, 2014). By 2015, 2,735 reports had been submitted to the Ministry of Justice; more than 11,500 personal enquiries had been answered; and more than 2,000 queries had been made by researchers.

In addition, the research work on the forms of registration of the information by the intelligence institution enabled concise explanation of the way the information had been produced and the links with other intelligence agencies (the so-called information community) for the purposes of political and ideological persecution and necessary for the system of repression to function.

As one newspaper article stated, "Information which enabled a subversive individual to be kidnapped produced further information, even if this was gathered through torture, and was remitted once again to the local authority, constituting a cyclical, constant and perverse methodology" (Andar, 13/08/2015). The Buenos Aires Provincial Memory Committee (CPM) even appeared as a plaintiff in the case investigating the actions of the DIPPBA, in the planning and execution of state terrorism. ${ }^{12}$

The next case is that of the Ministry of Defence. As noted, in 2009, a team by the name of the Survey and Analysis Team (Equipo de Relevamiento $y$ Análisis) was set up within the Human Rights and International Humanitarian Law Department to collect and analyse documentation of historical and/or legal value in order to collaborate in responding to requests for information from the Judiciary. This team began examining the archives of the Armed Forces, finding that they were not organised according to any clear criteria and that there were no measures in place for the preservation of the documents. For this reason, and with the technical assistance of the General Archive of the Nation (AGN: Archivo General de la Nación), the Modernisation Programme for the Defence Archive System (Programa de Modernización del Sistema de Archivos del Área de la Defensa) was created with the aim of designing, developing and implementing an archive management model to identify, classify, inventory and improve the conditions of preservation of the documents and undertake their digitization.

This work facilitated the task of the investigation teams, which have made extremely valuable contributions to Justice departments, especially by preparing reports on the functional structures of the repressive apparatus, presenting evidence on the chains of command, the circuits and functioning of information and the types of action taken. Most of the investigations 


\section{Mariana Nazar}

have been based on the analysis of the documentation carried out by different personnel qualification boards in the Armed Forces, to assess the performance of personnel. This documentation details the format of rewarding the fight against subversion and, in some cases, the specific mention of an episode.

Other documentation widely used are the Historical Annals of each unit, containing their annual report. For the case of the army "this document is fundamental since it enables identification, year by year, of the inspection personnel in the unit, besides adding relevant information" (Lavintman, López and Pankonin, 2017). Action taken by the military justice apparatus has also been widely accessed by the investigation teams; particularly when they commenced work to check whether episodes of illness, accident, desertion and/or salary embargoes of personnel were linked to acts of service. These include accounts of repressive action, references to the contexts in which this took place, and details of those involved.

Finally, the document fonds, the Supreme Council of the Armed Forces (CONSUFA: Consejo Supremo de las FF.AA.), which holds the documentation of Military Justice, was transferred and is open to public consultation at the AGN. This fonds also provides a great deal of information on clandestine repressive action. In the summaries, testimonies can be found from both civilians and members of the operations force that culminated in kidnappings and disappearances. Declarations giving an account of the final fate of the bodies of disappeared persons have even been identified. In addition, the Modernisation Programme managed to transform, and reverse, the sense of inaccessibility of the armed forces archives, ushering in the need for a public opening, as a way of collaborating with the basic requirements of the democratic state, and producing tools for their effective compliance, such as the archive guide and regulations on access. ${ }^{13}$ Both the reports of the investigation teams and the archive guides are available on the web in a tab on the Ministry of Defence webpage, entitled Open Archives (Archivos Abiertos)..$^{14}$

By mentioning these two cases, what we are trying to point out is the importance of the type of treatment given to archive documents in these cases. In other cases, which began with the perspective of memory or contribution to justice, certain types of documents or information were selected for their preservation or circulation, and access was denied (either actively or passively, by omission) to the rest of the documentation which would have shed light on this, thus supplementing the information. This information could have been read, taking a different viewpoint - or using other techniques developed years later. Although the use of certain documents was permitted, their preservation in the permanent and professional archive infrastructure typical of any State was not ensured in the long term. ${ }^{15}$ As noted previously, the archives were manipulated.

In a way, in this concealment of archiving tasks, the government became both victim and perpetrator, because it created the conditions to prevent 
good archive practice from being considered when designing both the rules and strategies adopted for documentation on human rights violations. Faced with designing memory-centred policies in a context of absence of official public archive policies, it was in the field of concrete practices that processing choices were made. And this depended, to a great extent, on the situation and technical and professional links of the key players in the process.

This same weakness, at some point, reinforced the perception that this had been a government policy, without this managing to take root and establish itself as a public, state-led policy.

The new presidency resulting from the 2015 elections implied a radical change, among other things, in public policies on human rights. The newly elected president, Mauricio Macri, had declared the previous year that if he became president, there would be no more "human rights jobs" (La Nación, 08/12/2014). After his electoral victory, several of the programmes suffered cuts in their budget, personnel and functions. By March 2016, the investigation teams and the Defence Archives System had cut their staff by a third, the Central Bank head office had dissolved the Human Rights Department, and the Ministry of Security dismissed the coordinators of the team working on the Gendarmerie and Federal Police archives, while the Human Rights Office Department was dissolved. As pointed out in a newspaper article of the time, in reference to the Ministry of Security, "Copies of the reconstruction of the internal regulations of the security forces and a census on the contents of the archives, which clarified structures and responsibilities in central aspects such as the death flights, literally ended up in rubbish bins" (Page 12, 28 December 2016).

\section{By way of conclusion}

Since the democratic opening of 1983, there have been several attempts to access information that would provide an account of the actions of the government during the Dictatorship, and in particular the fate of the missing persons.

Between 2003 and 2015, Argentina, as a state, produced a total change of paradigm by recognising the crimes that it had committed, facilitating the reopening of court cases and generating policies on its memory that included the preservation of, and access to, archives. We understand that these policies produced a movement of visibility and social condemnation of state-led terrorism, which would have been unthinkable 20 years earlier. At the same time, the reopening of the cases and the contribution to Justice has been considerable and effective, putting an end to a situation of impunity, contrary to national and international law, and recognising once again the dignity of those affected.

Nevertheless, in the area of archives, it has not been in the enactment of regulations that these policies have made a contribution. On the contrary, 
insofar as the state created these archive sites in a manner which was totally divorced from the regulations in force, and also divorced from the institutions traditionally responsible for carrying out these policies, it created these sites without providing the conditions for their work to be done efficiently.

\section{Notes}

1 By way of example, we have the conflicting statements that appeared in the press in January 1999, in reference to those made by Cristino Nicolaides to Judge Bagnasco and the public declaration by Martin Balza, the then Chief of the Army, claiming that there were no documents on the illegal repression. Clarín, 20/01/99 and 22/01/99.

2 Víctor Basterra was held captive for more than four years, from mid-1979 until the end of the military regime, although he continued under surveillance until August 1984, well into the democracy. He was kidnapped along with his wife and his newborn first daughter. With time, he was forced to forge documents (passports, identity cards and weapons permits) for officers and people with links to the Navy. This enabled him to make extra copies of photos and documents that were requested. When he began to obtain exit permits, he succeeded in taking out photos hidden in his underwear. In the trial of the Military Juntas, he gave the most convincing and longest testimony of the trial, providing all the photographic material and documentation that he had managed to obtain from the ESMA. For more information, see Brodsky, 2005; Larralde Armas, 2015.

3 Some examples are the lists of names and information on political militancy found during a visual inspection at the Automotores Orletti Clandestine Detention Centre in July 2006, which were found concealed in the walls, to cover up holes produced by bullets, and the documents found at the Customs office in Paso de los Libres, in the province of Corrientes. For more information, see Varsky et al., 2008.

4 One example is the article by BONASSO, Miguel: 'Lo que sabía el 601', on Página/12, 25/08/02, where a secret document from June 1980 is described, revealing some knowledge on Montoneros, in the hands of the Army. This can be found in Case 6859, in the charge of Judge Bonadío. Available at www.pagina12. com.ar/diario/elpais/1-9327-2002-08-25.html, accessed 28 February 2019.

5 The trial of the military Juntas (Juicio a las Juntas) is known as the trial of the members of the first three military Juntas during the dictatorship, undertaken by the civil justice system and initiated by a presidential decree, due to their grave and mass-scale human rights violations.

6 As Emilio Crenzel (2003, p. 79) points out, "the survivors who testify succeed in making it possible to transmit the topography of the horror to others; they are the master builders of their first map".

7 Compared to the purely economic reparations of the 1990 s, that can be identified as having an insurance policy format, as pointed out by de Greiff, "Reparations are not simply an exchange mechanism, similar to an insurance policy against criminal acts or a compensation system for victims when their rights have been violated. For something to count as reparation - as a measure of justice - it must be accompanied by the recognition of liability and linked, precisely, to truth, justice and guarantees of non-repetition" (United Nations, 2012).

8 Ley $\mathrm{N}^{\circ} 25.914$ Indemnización para Hijos; Ley $\mathrm{N}^{\circ} 26.564$ ampliación de los beneficios de las leyes $\mathrm{N}^{\circ} 24.043 \mathrm{y} \mathrm{N}^{\circ} 24.411$ y Ley $\mathrm{N}^{\circ} 24.043$ Indemnización para ex Detenidos. 
9 For a closer look at some of these institutions and the documentation they hold, see Guía de archivos útiles para la investigación judicial de delitos de lesa humanidad produced by Memoria Abierta. Available at www.fiscales.gob.ar/ lesa-humanidad/wp-content/uploads/sites/4/2013/08/archivos_investigacion_ judicial.pdf.

10 The concept of manipulation of archives is used to refer to situations where documents are managed on the basis of the need to complete one of the social functions of the archives: either to provide sources for history; or to serve for the institutional "memory"; or to contribute to justice. By focusing the tasks on serving one of these functions, the documents receive individual treatment in some, several or all archiving tasks (preservation, identification, classification, arrangement, assessment, description and access), often losing the completeness of their fonds and the context in which they were produced. See Nazar for the presentation of a case, 2018.

11 See Cesáreo and Novarini, 2013. Available at www.comisionporlamemoria.org/ static/prensa/archivo/cuadroclasificacion/\#seccion3.

12 This can be seen in an educational audiovisual available at www.youtube.com/ watch? $v=d C t S 2$ bdgjcY.

13 The result of this process can be seen at www.argentina.gob.ar/defensa/ archivos-abiertos/instituciones-de-archivo.

14 Available at www.argentina.gob.ar/defensa/archivos-abiertos.

15 See Nazar, 2008, 2012 for a more in-depth analysis.

\section{Bibliography}

Brodsky, Marcelo. 2005, Memoria en construcción: El debate sobre la ESMA. La Marca: Buenos Aires.

Cesáreo, Marina, and García Novarini, Cecilia. 2013, “Una estructura jerárquica conservadora se aggiorna: el Proyecto de Modernización de los Archivos del Área de la Defensa del Ministerio de Defensa," in: Actas XIV Jornadas Interescuelas/ Departamentos de Historia. Mendoza: Universidad Nacional de Cuyo. Available at www.aacademica.org/000-010/848.

Comisión Nacional Sobre Desaparición de Personas. 1997, Nunca más. Buenos Aires: Eudeba.

Crenzel, Emilio. 2003, El testimonio en una memoria ciudadana: el informe Nunca más. Buenos Aires: Revista de Estudios Avanzados.

—. 2015, "La reconstrucción de un universo: desaparición forzada de personas en la Argentina," in: Aguirre, Carlos, and Villa-Flores, Javier (coord.), From theAshes of History. Loss and Recovery of Archives and Libraries in Modern Latin America, Carolina del Norte. Editorial A Contracorriente. Available at https://uncpress.org/book/9780985371555/from-the-ashes-of-history/.

Lanteri, Magdalena, and Nazar, Mariana. 2014, "A 10 años de la apertura del Archivo de la DIPPBA. First Panel: Presentación de los instrumentos de descripción del fondo documental de la ex DIPPBA," Aletheia, vol. 5, no. 9, October. Available at www.aletheia.fahce.unlp.edu.ar/numeros/numero-9/conferencias/a10-anos-de-la-apertura-del-archivo-de-la-dippba--primer-panel-presentacion-delos-instrumentos-de-descripcion-del-fondo-documental-de-la-ex-dippba, accessed 28 February 2019.

Larralde Armas, Florencia. 2015, "Las fotos sacadas de la ESMA por Victor Basterra en el Museo de Arte y Memoria de La Plata: el lugar de la imagen en los 
trabajos de la memoria de la última dictadura militar argentina," in: Cuadernos del Centro de Estudios de Diseño y Comunicación $N^{\circ} 54$. Buenos Aires. Available at https://fido.palermo.edu/servicios_dyc/publicacionesdc/vista/detalle_articulo. php?id_articulo=10591\&id_libro=511, última visita 28 February 2019.

Lavintman, J., López, H., and Pankonin, L. 2017, “Conocimiento histórico y justicia: el trabajo en el Archivo del Ejército Argentino,” Aletheia, vol. 7, no. 14. Available at www.memoria.fahce.unlp.edu.ar/art_revistas/pr.7890/pr.7890.pdf.

Nazar, Mariana. 2008, "Dictadura, archivos y accesibilidad documental: A modo de agenda," in: Derechos humanos en Argentina. Informe 2007, Informe Anual del CELS. EUDEBA. Available at https://www.liverpooluniversitypress.co.uk/ journals/article/31874/.

- 2012, "Archivos, memoria y derechos: reflexiones en torno al caso argentine," in: Comma 2010.2. Liverpool: Revista del Consejo Internacional de Archivos.

- 2018, "Secretos, reservados y confidenciales: la producción de información de las fuerzas armadas y de seguridad como fuente para la historiografía," en Estudios Sociales del Estado, vol. 4, no. 7.

United Nations. 2012, A/HRC/21/46 Informe del Relator Especial sobre la promoción de la verdad, la justicia, la reparación y las garantías de no repetición. Pablo de Greiff. Available at www.ohchr.org/Documents/HRBodies/HRCouncil/ RegularSession/Session21/AHRC-21-46_sp.pdf.

Varsky, Carolina, Barbuto, Valeria, Martínez, Diego, and Parellada, Julieta. 2008, "Justicia por los crímenes de la dictadura," in: Derechos humanos en Argentina. Informe 2007, Informe Anual del Cels. EUDEBA. Available at www.cels.org.ar.

\section{Articles}

Andar. 2015, "Causa DIPPBA, dossier: la inteligencia fue terrorismo de estado," 13 August. Available at www.andaragencia.org/causa-dippba-dossier-la-inteligenciafue-terrorismo-de-estado/, última visita 28 February 2019.

Page12. 2016, Instrucciones para terminar con una política de Estado, 28 December. Available at www.pagina12.com.ar/diario/elpais/1-295579-2016-03-28.html, accessed 28 February 2019.

La Nación. 2014, Mauricio Macri: 'Conmigo se acaban los curros en derechos humanos', 8 December. Available at www.lanacion.com.ar/politica/mauriciomacri-conmigo-se-acaban-los-curros-en-derechos-humanos-nid1750419. 